\title{
Studies of Sulfobromophthalein Sodium (BSP) Metabolism in Man. II. The Effect of Artificially Induced Fever, Norethandrolone (Nilevar), and Iopanoic Acid (Telapaque) *
}

\author{
Leslie J. Schoenfield and William T. Foulk \\ (From the Section of Medicine and the Gastrointestinal Research Unit, Mayo Clinic and Mayo \\ Foundation, Rochester, Minn.)
}

The disappearance of sulfobromophthalein sodium (BSP) from the blood after its intravenous administration is a result of a complex of processes-hepatic uptake, storage, conjugation, and biliary excretion of the dye (1). Fever and the administration of anabolic steroids are among the factors that may influence the metabolism of BSP.

In an attempt to determine the mechanisms of abnormal BSP retention induced by anabolic steroids and fever, we studied the effects of norethandrolone (Nilevar) ${ }^{1}$ and of a brief period of artificially induced fever upon transport of the dye. During compilation of normal values for fractional clearance of BSP (2), a depression of this transport parameter was encountered in a woman ultimately given the diagnosis of "irritablebowel syndrome." When we learned that the gallbladder contrast medium, iopanoic acid (Telepaque), ${ }^{2}$ had been ingested on the evening before study, we added to the original plan an investigation of the effect of this commonly used cholecystographic material on BSP metabolism. Consequently, this paper reports observations on alteration of BSP transport induced by artificial fever and by two chemical agents, norethandrolone and iopanoic acid.

\section{Methods}

The methods used for measuring the fractional clearance (percentage disappearance rate, $P D R$ ), retention of dye at 60 minutes, and the proportion of serum BSP found in conjugated forms after a single intravenous

* Submitted for publication December 23, 1963 ; accepted February 27, 1964.

This investigation was supported in part by research grant AM-06908 from the National Institutes of Health.

1 G. D. Searle, Chicago, Ill.

${ }^{2}$ Winthrop Laboratories, New York, N. Y. injection of the dye have been described previously (2). Measurement of maximal biliary excretion ( $\mathrm{Tm}$ ) and relative hepatic storage capacity $(\mathrm{S})$ for BSP during its constant infusion have been described also $(2,3)$. In all instances normal healthy subjects were studied.

Fever. Fractional clearance, retention of the dye at 60 minutes, and proportion of serum BSP in conjugates after a single intravenous injection of the dye were determined in six subjects. Each subject was studied on three occasions: at least one day before artificially induced fever, during the febrile episode, and the day after.

The subject was placed supine in a moist-heat, feverproducing cabinet with only his head exposed. About 1 hour was required to elevate the body temperature to $103^{\circ} \mathrm{F}$ as recorded by an electrical rectal thermometer. This temperature was maintained for the determination of fractional clearance and then permitted to drift back toward normal. In most instances the temperature was about $2^{\circ} \mathrm{F}$ above the base-line level at the time the 1-hour blood sample was drawn for determination of BSP retention.

$\mathrm{Tm}$ and $\mathrm{S}$ for BSP were estimated in two additional healthy individuals with use of the constant-infusion technic of Wheeler, Meltzer, and Bradley (3). Fever was induced as described above, and rectal temperature greater than $103^{\circ} \mathrm{F}$ was maintained for about 45 minutes, the total febrile period being about $3 \frac{1}{2}$ hours. The constant infusion was started when the temperature returned to normal, and the results were compared with those of the control tests carried out 2 weeks earlier.

Norethandrolone. $\mathrm{PDR}$ and serum retention of BSP at 60 minutes were determined in two healthy persons. $\mathrm{Tm}$ and $\mathrm{S}$ were estimated, and conjugates in the serum were measured during the course of constant BSP infusion. All of the tests were repeated after the two subjects had ingested norethandrolone, $10 \mathrm{mg}$, three times a day for 10 days, and again after 1 month without further medication.

Iopanoic acid. Addition of iopanoic acid to a known amount of BSP in serum left the optical density unaltered, demonstrating that the contrast medium itself did not interfere with the BSP determination. Fractional clearance and 60-minute serum retention of BSP were determined in four healthy subjects on three occasions, and each serum specimen was analyzed for BSP metabo- 
lites. The first test was done on the morning before ingestion of the standard dose of iopanoic acid (four $0.5-\mathrm{g}$ tablets), the second on the following morning (12 to 14 hours after the ingestion), and the third 2 days later. $\mathrm{Tm}$ and $\mathrm{S}$ for BSP were determined in two additional normal persons on three occasions at weekly intervals, with iopanoic acid administered orally on the evening preceding the second test. BSP conjugates also were measured during the course of the constant infusions.

\section{Results}

Fever. No significant untoward effects were noted during the tests involving fever. Headache, nausea, and restlessness occurred during the febrile period in most subjects but subsided rapidly with defervescence.

Table I shows the values for fractional clearance of BSP in each of six normal subjects during the tests made before, during, and after artificially induced fever. The results of three repeat measurements of PDR at similar time intervals but without induced fever in four other normal subjects ( 1 to 4 , Table II) were similar to those of this test series. In all instances, including those following the various procedures, a straight-line PDR could be determined with a semilogarithmic plot of serum BSP concentrations obtained at 5-minute intervals for 15 minutes after the injection of BSP.

BSP conjugates were not present in serum samples obtained at 5,10 , or 15 minutes after the intravenous injection of BSP in the control studies or those done during fever. BSP retention at 60 minutes was insignificant, in that all the samples gave values less than $5 \%$ and contained insufficient dye for satisfactory quantitative paper chromatographic determination of conjugated BSP.

TABLE I

Effect of artificially induced fever on fractional clearance of $B S P$ in six normal subjects

\begin{tabular}{ccc}
\hline \hline Before & $\begin{array}{c}\text { During } \\
\text { fever }\end{array}$ & $\begin{array}{c}18-30 \\
\text { hours } \\
\text { after }\end{array}$ \\
\hline$\% /$ minule & $\% /$ minute & $\begin{array}{c}\% / \text { minute } \\
11.0\end{array}$ \\
14.7 & 11.2 & 12.8 \\
11.0 & 13.0 & 15.4 \\
12.5 & 11.6 & 11.4 \\
14.1 & 11.6 & 12.4 \\
10.7 & 12.8 & 13.3 \\
& 11.7 & 11.9 \\
\hline
\end{tabular}

In two subjects given a constant infusion of BSP immediately after a $3 \frac{1}{2}$-hour period of fever, Tm and $\mathrm{S}$ were not altered (Table III), and the pattern of serum BSP conjugates was normal (2).

Norethandrolone. The effects of norethandrolone ingestion on PDR, Tm, and $\mathrm{S}$ are shown in Table IV. With ingestion of norethandrolone, both subjects exhibited a decrease in PDR, which 1 month later returned toward the control value. This decrease from the control value was greater than the normal variance disclosed by repeat tests using four other normal subjects ( 1 to 4 , Table II). BSP retention 60 minutes after intravenous injection of the dye was less than $5 \%$ in each test, including those made when norethandrolone had been ingested for 10 days preceding. BSP conjugates were not found in the serum samples obtained at 5,10 , or 15 minutes after a single intravenous injection of $\mathrm{BSP}$ in the control tests or those done after ingestion of norethandrolone. Coincident with this medication, Tm decreased from the control value by more than the normal variance for repeat tests in four normal subjects. There was no significant change in S. During the continuous infusion of BSP after administration of norethandrolone, the regression of the proportion of serum BSP in conjugated form on time resembled that shown to occur in biliary obstruction (2), contrasting with the findings from control tests of both subjects.

Iopanoic acid. Table II shows the effects of in-

TABLE II

Effect of iopanoic acid on $P D R, T m$, and $S$ of $B S P^{*}$

\begin{tabular}{|c|c|c|c|c|c|}
\hline Parameter & Condition & $\begin{array}{l}\text { Sub- } \\
\text { jects }\end{array}$ & $\begin{array}{c}\text { Initial } \\
\text { test }\end{array}$ & $\begin{array}{c}\text { Second } \\
\text { test }\end{array}$ & $\underset{\text { test }}{\text { Final }}$ \\
\hline \multirow{8}{*}{$\begin{array}{l}\text { PDR, } \\
\% / \text { minute }\end{array}$} & \multirow{4}{*}{ Control } & 1 & 12.4 & 11.7 & 13.2 \\
\hline & & 2 & 13.3 & 13.0 & 12.1 \\
\hline & & 3 & 13.6 & 11.9 & 12.3 \\
\hline & & 4 & 10.2 & 12.2 & 10.7 \\
\hline & \multirow{4}{*}{$\begin{array}{c}\text { Iopanoic } \\
\text { acid } \dagger\end{array}$} & 5 & 11.4 & 8.9 & 11.7 \\
\hline & & 6 & 12.4 & 8.2 & 13.1 \\
\hline & & 7 & 10.7 & 8.5 & 11.2 \\
\hline & & 8 & 13.3 & 11.8 & 13.0 \\
\hline \multirow{2}{*}{$\begin{array}{l}\text { Tm, } \\
\quad m g / m i n u t e\end{array}$} & \multirow{2}{*}{$\begin{array}{c}\text { Iopanoic } \\
\text { acidt }\end{array}$} & 9 & 7.4 & 5.2 & 7.7 \\
\hline & & 10 & 8.0 & 5.9 & 8.4 \\
\hline S, & Iopanoic & 9 & 80.7 & 122.0 & 74.4 \\
\hline $\mathrm{mg} / \mathrm{mg} / 100 \mathrm{ml}$ & acidt & 10 & 44.8 & 74.4 & 52.6 \\
\hline
\end{tabular}

* PDR = fractional clearance; $\mathrm{Tm}=$ maximal biliary excretion

$S=$ relative storage capacity.
† Iopanoic acid ingested on evening before second test; final deter† Iopanoic acid ingested on evening before second test; final deter-
minations of PDR performed 2 days later, of $T \mathrm{~m}$ and $\mathrm{S} 1$ week later. 
gestion of iopanoic acid on PDR, Tm, and $S$ in four normal subjects. Three of the four exhibited significant diminution of PDR when tested on the morning after iopanoic acid had been taken. The fourth subject (No. 8) also showed a reduction of PDR on this occasion and a return to the control value 2 days later, but this reduction was not greater than the variance that might occur by chance in a repeat test. BSP metabolites were not demonstrated in serum specimens taken from these subjects at 5,10 , and 15 minutes after the intravenous administration of the dye. BSP retention at 60 minutes was less than $5 \%$ after ingestion of iopanoic acid, except in one subject whose retention was $12 \%$, with $25 \%$ of the total serum BSP in the conjugated form. In both subjects so tested after taking iopanoic acid, Tm was reduced and $\mathrm{S}$ was increased from levels found in the control tests. The pattern of serum BSP metabolites during the course of the constant infusions after ingestion of iopanoic acid resembled that which occurs with biliary obstruction (2) but returned to normal 2 days later.

\section{Discussion}

In these experiments, uptake of BSP by the liver in healthy subjects was not affected by induced fever, nor was conjugation, $\mathrm{S}$, or $\mathrm{Tm}$ for this dye influenced by a brief period of artificially induced fever in two additional healthy subjects.

Bradley and Conan $(4,5)$ studied hepatic blood flow by BSP clearance technics and catheterization of the hepatic vein. They found that although the estimated hepatic blood flow increased after administration of typhoid vaccine or pyrogenic inulin, removal of BSP from the blood was diminished by as much as $50 \%$; they concluded that there was a reduction in BSP extraction by
TABLE III

Effect of artificially induced fever on Tm and $S$ of BSP

\begin{tabular}{|c|c|c|c|}
\hline \multicolumn{2}{|c|}{ Control study } & \multicolumn{2}{|c|}{ Day of fever } \\
\hline $\mathrm{Tm}$ & $\mathrm{s}$ & $\mathrm{Tm}$ & $\mathrm{s}$ \\
\hline mg/minute & $\begin{array}{c}\mathrm{mg} / \mathrm{mg} / \\
100 \mathrm{ml}\end{array}$ & mg/minute & $\begin{array}{c}\mathrm{mg} / \mathrm{mg} / \\
100 \mathrm{ml}\end{array}$ \\
\hline $\begin{array}{l}9.4 \\
8.8\end{array}$ & $\begin{array}{l}76.4 \\
71.0\end{array}$ & $\begin{array}{l}9.9 \\
8.6\end{array}$ & $\begin{array}{l}74.4 \\
75.1\end{array}$ \\
\hline
\end{tabular}

the liver. An increase of hepatic blood flow induced by fever or pyrogen would not necessarily alter BSP retention. Mendeloff, Kramer, Ingelfinger, and Bradley (6) reported that, within a limited range, an inverse relationship holds between hepatic blood flow and the proportion of BSP extracted by the liver. Thus the proportional disappearance rate of BSP from the blood may be maintained in the face of circulatory changes.

Evidence for the influence of fever on BSP retention is conflicting. Increase of hepatic blood flow and reduction in BSP extraction occurred in Bradley's study (4) when pyrogenic fever was prevented by premedication with aminopyrine. Hicks, Holt, Guerrant, and Leavell (7), however, found that administration of foreign protein that was not followed by temperature elevation left BSP clearance unimpaired. Whether fever per se or some concomitant hepatocellular toxic agent is responsible for BSP retention in febrile illness remains unclear. Hicks and associates (7) found that retention of BSP was increased in four subjects with fever induced by external heat. In three of the four, dye retention after $45 \mathrm{~min}$ utes was less than $10 \%$; the fourth subject retained more than $30 \%$ of administered Bromsulphalein at 45 minutes. The discrepancy between these findings and the results of our study

TABLE IV

Effect of norethandrolone (Nilevar) on Tm, S, and PDR for BSP

\begin{tabular}{|c|c|c|c|c|c|c|c|c|}
\hline \multicolumn{3}{|c|}{ PDR } & \multicolumn{3}{|c|}{$\mathbf{s}$} & \multicolumn{3}{|c|}{$\mathrm{Tm}$} \\
\hline Control & Nilevar* & 1 month & Control & Nilevar* & 1 month & Control & Nilevar* & 1 month \\
\hline \multicolumn{3}{|c|}{$\% /$ minute } & \multicolumn{3}{|c|}{$\mathrm{mg} / \mathrm{mg} / 100 \mathrm{ml}$} & \multicolumn{3}{|c|}{ mg/minute } \\
\hline $\begin{array}{l}11.6 \\
10.7\end{array}$ & $\begin{array}{l}9.4 \\
8.7\end{array}$ & $\begin{array}{r}11.0 \\
9.9\end{array}$ & $\begin{array}{l}72.8 \\
66.5\end{array}$ & $\begin{array}{l}65.8 \\
82.0\end{array}$ & $\begin{array}{l}71.0 \\
76.4\end{array}$ & $\begin{array}{l}9.2 \\
9.5\end{array}$ & $\begin{array}{l}6.3 \\
6.3\end{array}$ & $\begin{array}{l}8.8 \\
9.4\end{array}$ \\
\hline
\end{tabular}

* $30 \mathrm{mg}$ daily for 10 days. 
is difficult to explain. Dye retention was determined at 60 minutes in our subjects, all of whom were normal, nonhospitalized volunteers. Differences in the subjects and in duration of fever might be factors in the divergence of results. Conceivably, fever more prolonged than was induced in our experiments-perhaps of such a duration as usually would occur in febrile illnesscould alter BSP transport. But the short period of artificially induced fever in our tests did not alter this parameter of hepatic function.

Liver dysfunction as a result of the administration of norethandrolone has been well documented (8), and abnormal BSP retention has been shown to occur in most persons who ingest enough norethandrolone (9). Whether the changes noted in the biliary canaliculi by Schaffner, Popper, and Chesrow (10) are related to the functional defect in BSP transport remains open to question (11). Heaney and Whedon (12), finding that after administration of norethandrolone the first exponential portion of the BSP disappearance curve showed no gross change but that the second exponential had a longer halftime, suggested that the defect in clearance of BSP involves the hepatic excretory mechanism rather than hepatic uptake of the dye. Decrease of Tm for BSP was the only evidence of hepatic dysfunction observed by Scherb, Kirschner, and Arias (11), after giving 17-ethyl-19nortestosterone. They suggested that this drug interferes with the transfer of BSP conjugates from the liver cell to the bile. Leevy, Cherrick, and Davidson (13) reported defects in hepatic uptake and also excretion of BSP after norethandrolone. A normal or even increased $\mathrm{S}$ does not imply that the measurements representing decreased hepatic uptake necessarily reflect impaired Tm.

Shotton, Carpenter, and Rinehart (14) found a 45-minute BSP retention increased in normal subjects and in patients with liver disease after ingestion of bunamiodyl (Orabilex), ${ }^{3}$ a commonly used gall-bladder dye. They suggested that this iodine-containing compound competes with the bromide-containing BSP for the hepatic transport mechanisms. Ingestion of bunamiodyl has been reported also to cause an increase of serum

\footnotetext{
${ }^{3}$ E. Fougera, Hicksville, N. Y.
}

bilirubin concentration that may persist up to 48 hours (15). Bolt, Dillon, and Pollard postulated that the contrast medium may block uptake of bilirubin and BSP by parenchymal cells. Although iopanoic acid was reported not to affect retention of either bilirubin or BSP, three of eight subjects in their study receiving this medium exhibited a slight increase in BSP retention. Findings from our studies after ingestion of iopanoic acid suggest that it may cause a defect in hepatic uptake and biliary excretion of BSP with increased reflux of conjugated BSP during the course of continuous infusion of the dye. After a single injection, abnormal BSP retention at 60 minutes occurred in only one of four subjects tested. How an apparent increase of $\mathrm{S}$ is related to abnormalities of the other parameters of BSP metabolism is not clear.

\section{Summary}

Measurements of fractional clearance, 60-minute serum retention, relative storage capacity, conjugation, and maximal biliary excretion of sulfobromophthalein sodium (BSP) in healthy volunteers were not influenced by a brief period of artificially induced fever. Ingestion of norethandrolone (Nilevar) and of iopanoic acid (Telepaque) resulted in apparent defects of both hepatic uptake and biliary excretion of BSP. Increased reflux of conjugated BSP into the serum was noted during the course of continuous infusion of dye after administration of each drug. Because contrast medium may interfere with BSP transport, it seems preferable that gall-bladder dye not be administered before determination of BSP retention as a clinical test of hepatic function.

\section{References}

1. Combes, B., and G. S. Stakelum. A liver enzyme that conjugates sulfobromophthalein sodium with glutathione. J. clin. Invest. 1961, 40, 981.

2. Schoenfield, L. J., W. T. Foulk, and H. R. Butt. Studies of sulfobromophthalein sodium (BSP) metabolism in man. I. In normal subjects and patients with hepatic disease. J. clin. Invest. 1964, 43, 1409.

3. Wheeler, H. O., J. I. Meltzer, and S. E. Bradley. Biliary transport and hepatic storage of sulfobromophthalein sodium in the unanesthetized dog, in normal man, and in patients with hepatic disease. J. clin. Invest. 1960, 39, 1131.

4. Bradley, S. E., and N. J. Conan. Estimated hepatic 
blood flow and bromsulfalein extraction in normal man during the pyrogenic reaction (abstract). J. clin. Invest. 1947, 26, 1175.

5. Bradley, S. E. Variations in hepatic blood flow in man during health and disease. New Engl. J. Med. 1949, 240, 456.

6. Mendeloff, A. I., P. Kramer, F. J. Ingelfinger, and S. E. Bradley. Studies with bromsulfalein. II. Factors altering its disappearance from the blood after a single intravenous injection. Gastroenterology 1949, 13, 222.

7. Hicks, M. H., H. P. Holt, J. L. Guerrant, and B. S. Leavell. The effect of spontaneous and artificially induced fever on liver function. J. clin. Invest. 1948, 27, 580.

8. Kory, R. C., M. H. Bradley, R. N. Watson, R. Callahan, and B. J. Peters. A six-month evaluation of an anabolic drug, norethandrolone, in underweight persons. II. Bromsulphalein (BSP) retention and liver function. Amer. J. Med. 1959, 26, 243.

9. Marquardt, G. H., C. I. Fisher, P. Levy, and R. M. Dowben. Effect of anabolic steroids on liver function tests and creatine excretion. J. Amer. med. Ass. 1961, 175, 851.
10. Schaffner, F., H. Popper, and E. Chesrow. Cholestasis produced by the administration of norethandrolone. Amer. J. Med. 1959, 26, 249.

11. Scherb, J., M. Kirschner, and I. Arias. Studies of hepatic excretory function. The effect of $17 \alpha-$ ethyl-19-nortestosterone on sulfobromophthalein sodium (BSP) metabolism in man. J. clin. Invest. 1963, 42, 404.

12. Heaney, R. P., and G. D. Whedon. Impairment of hepatic Bromsulphalein clearance by two 17-substituted testosterones. J. Lab. clin. Med. 1958, 52, 169.

13. Leevy, C. M., G. R. Cherrick, and C. S. Davidson. Observations on norethandrolone-induced abnormalities in plasma decay of sulfobromophthalein and indocyanine green. J. Lab. clin. Med. 1961, 57, 918.

14. Shotton, D., M. Carpenter, and W. B. Rinehart. Bromsulfalein retention due to administration of a gall-bladder dye (bunamiodyl). New Engl. J. Med. 1961, 264, 550.

15. Bolt, R. J., R. S. Dillon, and H. M. Pollard. Interference with bilirubin excretion by a gallbladder dye (bunamiodyl). New Engl. J. Med. 1961, 265, 1043. 